\title{
Riemerella anatipestifer gen. nov., comb. nov., the Causative Agent of Septicemia Anserum Exsudativa, and Its Phylogenetic Affiliation within the Flavobacterium- Cytophaga rRNA Homology Group
}

\author{
P. SEGERS, ${ }^{1}$ W. MANNHEIM, ${ }^{2}$ M. VANCANNEYT, ${ }^{1}$ K. DE BRANDT,${ }^{1}$ K.-H. HINZ, ${ }^{3}$ K. KERSTERS, ${ }^{1}$ \\ AND P. VANDAMME ${ }^{1,4 *}$ \\ Laboratorium voor Microbiologie, Ledeganckstraat 35, University of Ghent, B-9000 Ghent, ${ }^{1}$ and Department \\ of Microbiology, University Hospital, Antwerp, ${ }^{4}$ Belgium, and Klinikum der Philipps-Universität, Marburg, ${ }^{2}$ \\ and Klinik für Geflügel der Tierärztlichen Hochschule, Hannover, ${ }^{3}$ Germany
}

The phylogenetic position of the causative agent of septicemia anserum exsudativa, now most often referred to as [Moraxella] anatipestifer (brackets indicate a generically misnamed taxon) or " $[$ Pasteurella] anatipestifer," was established by performing rRNA cistron similarity studies. [Moraxella] anatipestifer belongs to rRNA superfamily V, together with the genera Flavobacterium, Cytophaga, Flexibacter, Weeksella, Capnocytophaga, and Sphingobacterium. The detailed structure of rRNA superfamily $V$, which now contains five major rRNA homology groups, is described. An analysis of various phenotypic parameters, including new data (cellular proteins and fatty acids) and previously published data (respiratory quinones, enzyme activities, and classical phenotypic features), revealed that [Moraxella] anatipestifer differs in many aspects from its closest relatives, Flavobacterium indologenes, Flavobacterium gleum, Flavobacterium indoltheticum, Flavobacterium balustinum, Flavobacterium meningosepticum, and Weeksella zoohelcum. The combined genotypic and phenotypic data indicate that this organism should be placed in a separate genus; the name Riemerella anatipestifer gen. nov., comb. nov. is proposed for this bacterium. The specific epithet anatipestifer is kept in order to avoid nomenclatural confusion. However, it should be emphasized that the illness caused by this organism is a septicemic disease which is not restricted to ducks.

The epizootic infectious disease of domestic birds known as septicemia anserum exsudativa was first described by Riemer in 1904 (30). The taxonomic status of few other bacteria has been changed as often as the taxonomic status of the organism causing this disease. The phylogenetic position of this organism remained unsettled (it was classified in various genera with several specific epithets) from 1904 until 1986, when Piechulla and coworkers described for the first time its correct affiliation with the FlavobacteriumCytophaga group (29). An overview of this nomenclatural odyssey was given by Floren et al. (14). At present, the organism is most often referred to as [Moraxella] anatipestifer (brackets indicate a generically misnamed taxon) or "[Pasteurella $]$ anatipestifer," and it is considered a species incertae sedis in Bergey's Manual of Systematic Bacteriology $(5,24)$. The numerous similarities between this organism and members of the Flavobacterium-Cytophaga group (lack of flagellation, low DNA base ratio, presence of menaquinones as the sole respiratory quinones, presence of branchedchain fatty acids in high percentages, absence of carbohydrate fermentation, and similar hydrolytic enzyme patterns) were significant parameters used to determine genomic relatedness, as shown by Rossau and coworkers (31). Rossau et al. also showed by performing a DNA-rRNA hybridization analysis that [Moraxella] anatipestifer indeed is not a close relative of the Moraxella or Pasteurella rRNA homology clusters but belongs to the Flavobacterium-Cytophaga rRNA homology cluster (31).

The phylogenetic relationships of the genera Flavobacterium, Cytophaga, and Flexibacter have been the subject of

\footnotetext{
* Corresponding author.
}

an on-going DNA-rRNA hybridization study performed during the past decade by members of the Ghent research group. Preliminary data were published by Bauwens and De Ley in 1981 (4), while a second set of data was presented recently during the Second International Symposium on Flavobacterium-Cytophaga and Related Bacteria in 1992 (32). However, only a phylogenetic tree was presented, with no hybridization values or strain numbers (32). Therefore, we describe in this paper the previous hybridization results and an extensive number of new data obtained from DNArRNA hybridization analyses and determinations of DNA base ratios. These results, together with those obtained from the protein and fatty acid analyses, are used below to show that the causative agent of the disease known as septicemia anserum exsudativa constitutes a separate taxon within the Flavobacterium-Cytophaga rRNA homology cluster. We propose the name Riemerella anatipestifer for this taxon and use this name below.

\section{MATERIALS AND METHODS}

Bacterial strains and growth conditions. All of the strains studied in the protein and fatty acid analyses are listed along with their sources in Table 1. The strains included in the DNA-rRNA hybridization analysis are listed in Table 2 . The $R$. anatipestifer strains and all of the reference strains included in the protein and fatty acid analyses except Flavobacterium balustinum $\mathrm{LMG} 8329^{\mathrm{T}}$ ( $\mathrm{T}=$ type strain) were grown on Trypticase soy agar (catalog no. 11768; BBL, Becton Dickinson Microbiology Systems, Cockeysville, Md.) and incubated at 36 to $37^{\circ} \mathrm{C}$ in a microaerobic atmosphere containing $5 \% \mathrm{O}_{2}, 10 \% \mathrm{CO}_{2}$, and $85 \% \mathrm{~N}_{2} ;$ Flavobacterium balustinum LMG $8329^{\mathrm{T}}$ was incubated at $28^{\circ} \mathrm{C}$. For 
TABLE 1. Strains studied in the protein and fatty acid analyses

\begin{tabular}{|c|c|c|}
\hline Strain $^{a}$ & Other designation(s) ${ }^{a}$ & Source, year, and place of isolation \\
\hline R. anatipestifer LMG 10957 & Hommez 3-8 & Duck, Belgium \\
\hline R. anatipestifer LMG 10988 & Hommez 5-25 & Chicken, Belgium \\
\hline R. anatipestifer LMG $11054^{\mathrm{T}}$ & CCUG $14215^{\mathrm{T}}$, ATCC $11845^{\mathrm{T}}$, MCCM $00568^{\mathrm{T}}$ & Duck blood, United States \\
\hline$R$. anatipestifer LMG 11056 & CCUG 25000, HPRS 1795 & Duck, United Kingdom, 1966-1969 \\
\hline R. anatipestifer LMG 11057 & CCUG 25001, HPRS 2591 & Duck, United Kingdom, 1966-1969 \\
\hline R. anatipestifer LMG 11059 & CCUG 25005, HPRS 2336 & Duck, United Kingdom, 1966-1969 \\
\hline R. anatipestifer LMG 11060 & CCUG 25054, HPRS 2560 & \\
\hline R. anatipestifer LMG 11524 & CCUG 25006, HPRS 1785 & Duck, United Kingdom, 1966-1969 \\
\hline R. anatipestifer LMG 11525 & CCUG 25008, HPRS 2174 & Duck, United Kingdom, 1966-1969 \\
\hline R. anatipestifer LMG 11526 & CCUG 25010, HPRS 2528 & \\
\hline R. anatipestifer LMG 11600 & MCCM 00761 & Turkey heart, Italy, 1987 \\
\hline R. anatipestifer LMG 11601 & MCCM 00762, K.-H. Hinz 46 & Duck, Germany, 1985 \\
\hline R. anatipestifer LMG 11602 & MCCM 00771, K.-H. Hinz 47 & Goose, Germany, 1985 \\
\hline$R$. anatipestifer LMG 11603 & MCCM 00772 & United States \\
\hline R. anatipestifer LMG 11604 & МCCM 00773 & United Kingdom, 1976 \\
\hline R. anatipestifer LMG 11605 & MCCM 00793, K.-H. Hinz 1 & Duck, Germany, 1981 \\
\hline Flavobacterium gleum LMG $8334^{\mathrm{T}}$ & CCUG $14555^{\mathrm{T}}$, NCTC $11432^{\mathrm{T}}$ & Vaginal specimen \\
\hline Flavobacterium indologenes $\mathrm{LMG} 8337^{\mathrm{T}}$ & CCUG $14556^{\mathrm{T}}$ & Trachea \\
\hline Flavobacterium indoltheticum LMG $4025^{\mathrm{T}}$ & ATCC $27950^{\mathrm{T}}$ & Marine mud \\
\hline Flavobacterium balustinum LMG $8329^{\mathrm{T}}$ & NCTC $11212^{\mathrm{T}}, \mathrm{LMG} 4010^{\mathrm{T}}$ & Fish heart \\
\hline Flavobacterium meningosepticum LMG $12279^{\mathrm{T}}$ & CCUG $214^{\mathrm{T}}$, ATCC $13253^{\mathrm{T}}$ & Human cerebrospinal fluid \\
\hline W. zoohelcum LMG $8351^{\mathrm{T}^{2}}$ & CCUG $12568^{\mathrm{T}}$ & Sputum, United States \\
\hline
\end{tabular}

${ }^{a}$ ATCC, American Type Culture Collection, Rockville, Md.; CCUG, Culture Collection of the University of Göteborg, Department of Clinical Bacteriology, University of Göteborg, Göteborg, Sweden; Hommez, J. Hommez, Provinciaal Verbond voor Dierenziektenbestrijding, Torhout, Belgium; HPRS, Houghton Poultry Research Station, Houghton, United Kingdom; LMG, Culture Collection of the Laboratorium voor Microbiologie, University of Ghent, Ghent, Belgium; MCCM, Medical Culture Collection of Microorganisms, Marburg, Germany; NCTC, National Collection of Type Cultures, London, United Kingdom.

DNA and rRNA preparation, $R$. anatipestifer and Capnocytophaga strains were incubated as described above; all other strains were incubated aerobically at $30^{\circ} \mathrm{C}$.

Bacteriological purity was checked by plating and examining living and Gram-stained cells. For mass cultures, cells were grown in Roux flasks.

Preparation of high-molecular-weight DNA. High-molecular-weight native DNA was prepared as described previously (39).

DNA base compositions. All of the guanine-plus-cytosine $(\mathrm{G}+\mathrm{C})$ values were determined by thermal denaturation and were calculated by using the equation of Marmur and Doty (25), as modified by De Ley (10).

Preparation of rRNA. To prepare radioactively labelled rRNA, ${ }^{3} \mathrm{H}$-labelled adenine or ${ }^{14} \mathrm{C}$-labelled uracil was added to early-log-phase cultures. In vivo radioactively labelled rRNAs from $R$. anatipestifer LMG $11054^{\mathrm{T}}$, Flavobacterium indologenes LMG $8337^{\mathrm{T}}$, and Weeksella zoohelcum LMG $8351^{\mathrm{T}}$ were prepared by using a slight modification of the procedure of Aiba et al. (1), as described by Vandamme et al. (38). In vivo radioactively labelled rRNAs from Flavobacterium breve LMG $4011^{\mathrm{T}}$, Flavobacterium aquatile LMG $4008^{\mathrm{T}}$, Capnocytophaga ochracea LMG $11546^{\mathrm{T}}$, Cytophaga heparina LMG $10339^{\mathrm{T}}$, and Sphingobacterium spiritivorum LMG $8347^{\mathrm{T}}$ were prepared as described by De Ley and De Smedt (11). Radioactively labelled rRNA from Cytophaga johnsonae LMG $1341^{\mathrm{T}}$ was prepared in a previous study (4). Flavobacterium aquatile $\mathrm{LMG} 4008^{\mathrm{T}}$ cells were grown on agar slopes in Roux flasks, whereas the other strains were grown in broth cultures as described by De Ley and De Smedt (11).

DNA-rRNA hybridization experiments. The methods used for fixation of single-stranded DNA on membrane filters, chemical determination of the amount of DNA on a filter, saturation hybridization, RNase treatment, and thermostability measurement of the hybrids were the methods described by De Ley and De Smedt (11).
Polyacrylamide gel electrophoresis of whole-cell proteins. Cells were grown for $48 \mathrm{~h}$ on one or two petri dishes. Whole-cell protein extracts were prepared, and sodium dodecyl sulfate-polyacrylamide gel electrophoresis was performed as described by Vauterin et al. (40).

Numerical analysis of the protein gel electropherograms. A densitometric analysis, normalization and interpolation of the protein profiles, and a numerical analysis were performed by using the GelCompar software package (Applied Maths, Kortrijk, Belgium). The profiles were recorded and stored on a PC-AT computer. The levels of similarity between pairs of traces were expressed by the Pearson product moment correlation coefficient converted for convenience to a percentage. The stacking gel-separation gel interface and the final part of the protein profile (the region containing proteins having molecular weights less than 20,100 [marker, trypsin inhibitor]) (see Fig. 2) were not used in the numerical analysis.

Fatty acid methyl ester analysis. Cells were grown for $48 \mathrm{~h}$ on one or two petri dishes. A loopful of well-grown cells was harvested, and fatty acid methyl ester extracts were prepared and analyzed by using the Microbial Identification System (Microbial ID, Inc., Newark, Del.) as described previously (39).

\section{RESULTS}

DNA base compositions. The average DNA base ratios determined are shown in Table 2.

DNA-rRNA hybridizations. The DNA-rRNA hybridization results are given in Table 2 and are shown as a dendrogram based on the melting temperatures of elution $\left[T_{m(e)}\right]$ of the hybrids in Fig. 1; each DNA-rRNA hybrid was characterized by the $T_{m(e)}$ value (the temperature at which $50 \%$ of the DNA-rRNA hybrid was denatured). A homologous duplex was formed between the DNA and rRNA of the same strain; a heterologous hybrid was formed between DNA and rRNA 


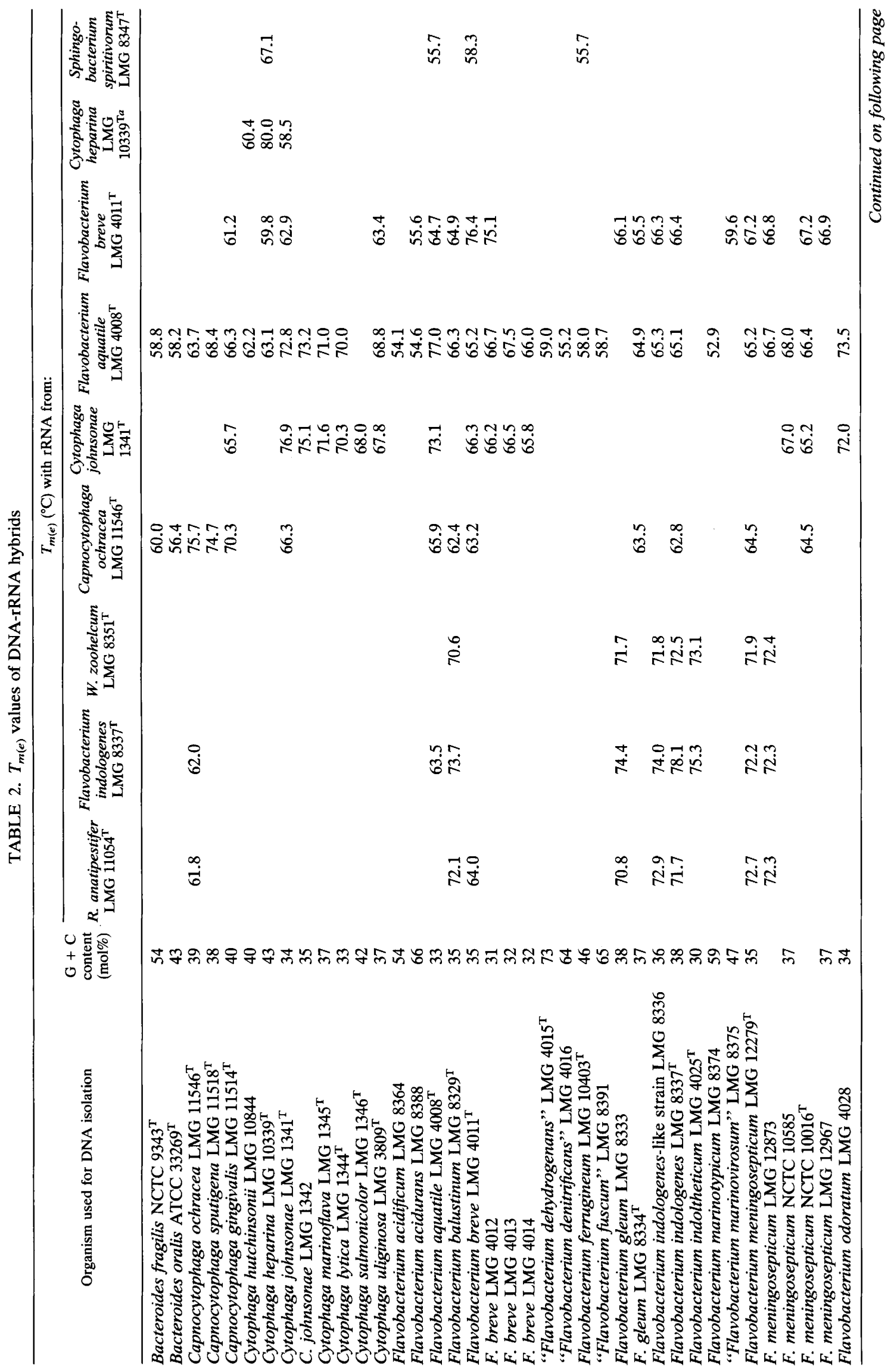




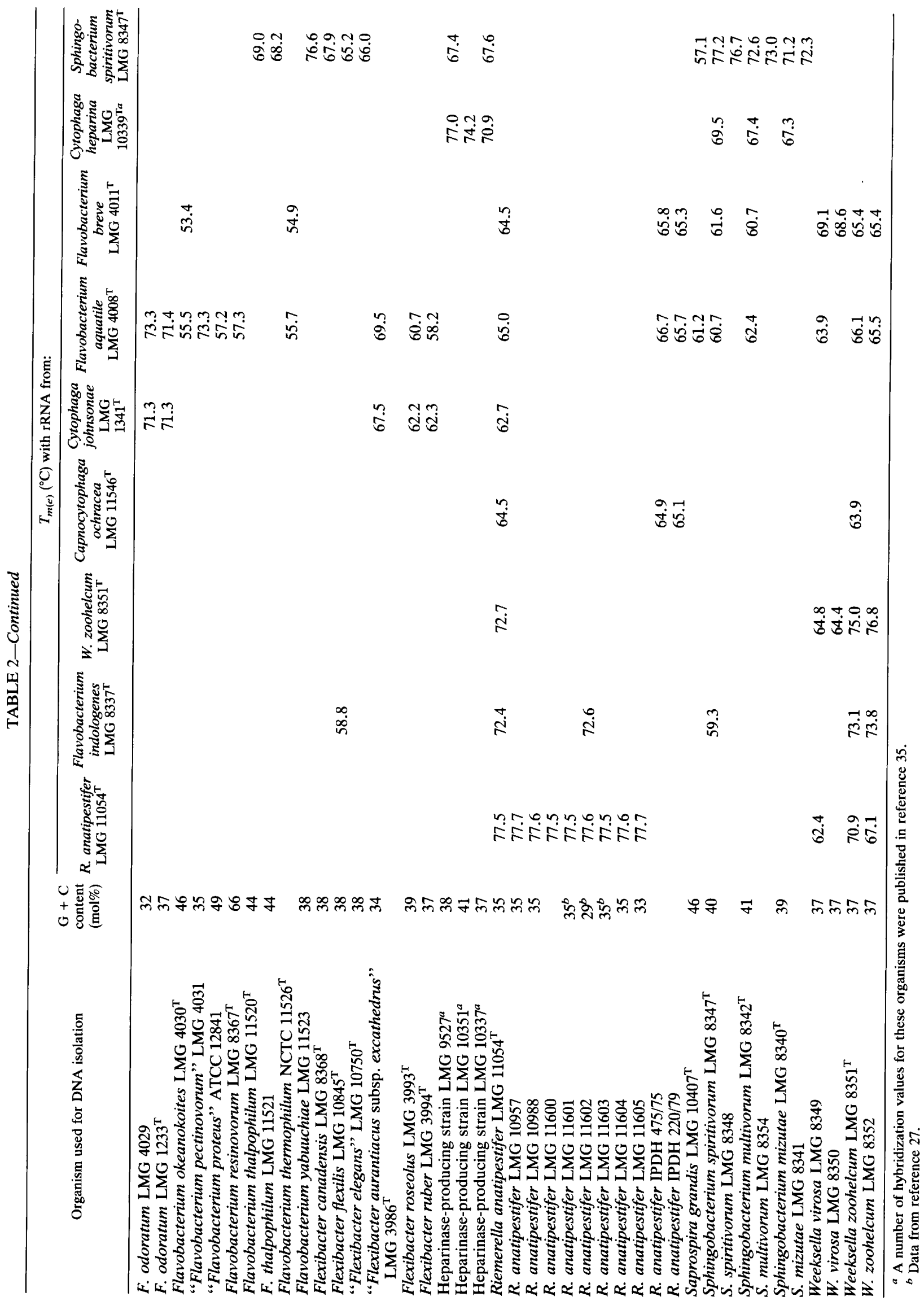




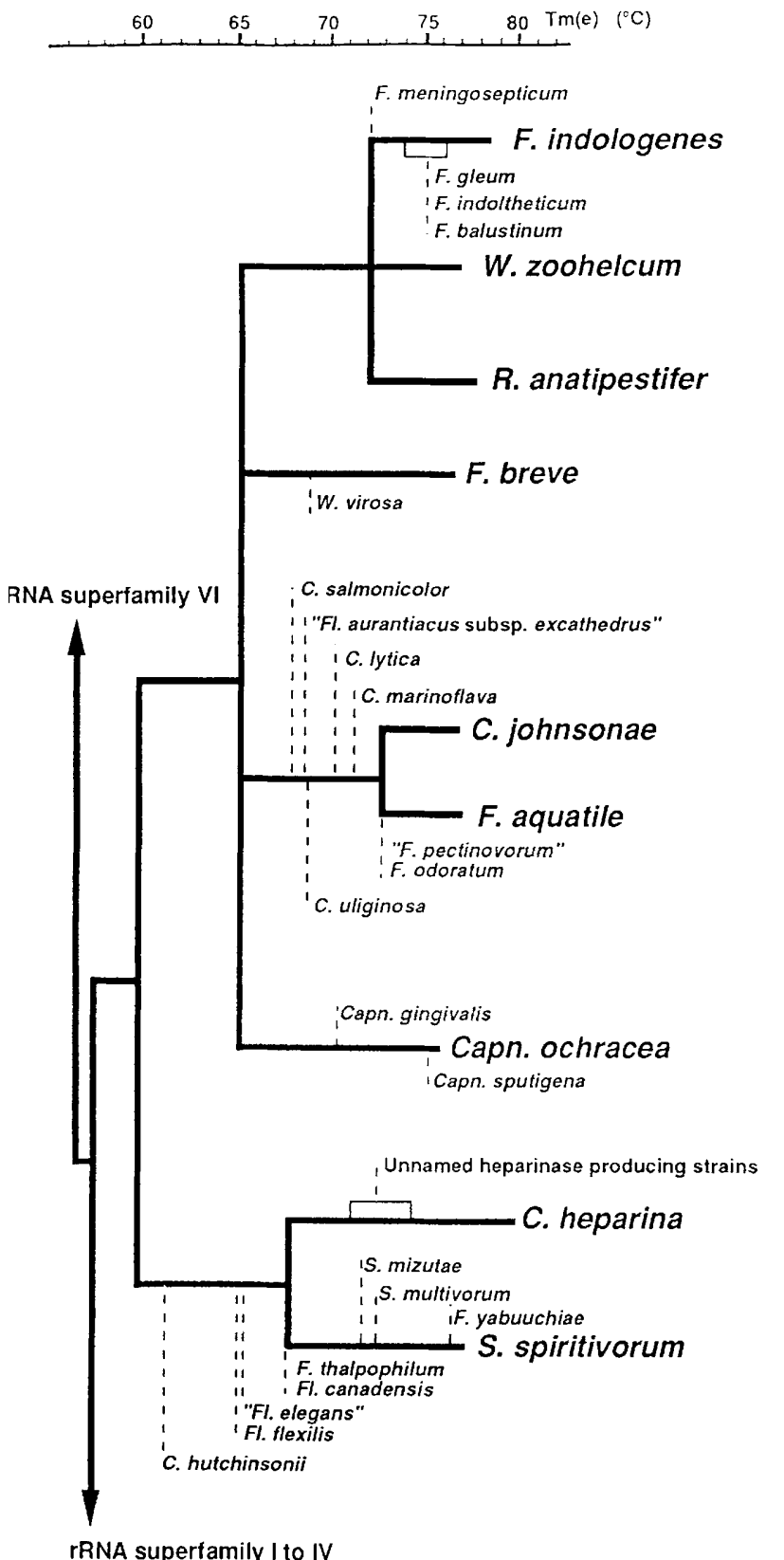

rRNA superfamily I to IV

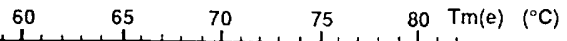

FIG. 1. Simplified rRNA cistron similarity dendrogram of rRNA superfamily V. Abbreviations: C., Cytophaga; Capn., Capnocytophaga; F., Flavobacterium, Fl., Flexibacter; R., Riemerella; S., Sphingobacterium; W., Weeksella.

of different strains. The $T_{m(e)}$ values from the reciprocal hybridization experiments obtained by using all strains of each rRNA branch were used to calculate the average linkage level between each pair of rRNA branches.

Polyacrylamide gel electrophoresis of whole-cell proteins. Duplicate protein extracts were prepared to check the reproducibility of the growth conditions and the preparation of the extracts. The correlation level between duplicate protein patterns was $\geq 0.95$ (Pearson product moment correlation coefficient).

The protein profiles of several $R$. anatipestifer strains were determined along with the profiles of reference strains belonging to the nearest phylogenetic neighbors of $R$. anatipestifer (Fig. 1). Figure 2 shows the protein profiles and the resulting numerical analysis data for all of the strains analyzed. All $R$. anatipestifer strains cluster together above a similarity level of $85 \%$. At this similarity level, all reference strains occupy separate positions.

Cellular fatty acid compositions. The fatty acid profiles of $R$. anatipestifer strains and reference strains belonging to the nearest phylogenetic neighbors of $R$. anatipestifer were determined. The average fatty acid composition of $R$. anatipestifer strains and the fatty acid compositions of the reference strains are shown in Table 3. Generally, branched fatty acids account for the majority of the fatty acid contents of all of the strains studied. Fatty acids 13:0 iso, 15:0 iso, 15:0 iso $3 \mathrm{OH}$, and 17:0 iso $3 \mathrm{OH}$ are the major fatty acids in $R$. anatipestifer. The Flavobacterium and Weeksella species studied lack high percentages of fatty acids 13:0 iso and 15:0 iso $3 \mathrm{OH}$. Furthermore, the latter organisms are characterized by the presence of two additional major fatty acids, iso 17:1 $\omega 9 \mathrm{c}$ and "summed feature 4."' As explained in Table 3, summed feature 4 comprises fatty acid 15:0 iso $2 \mathrm{OH}$ or $16: 1 \omega 7 \mathrm{t}$ or both. We cannot eliminate one of these fatty acids as both have been reported to be present in Flavobacterium species $(26,42)$.

\section{DISCUSSION}

The results of the DNA-rRNA hybridization analysis indicate that most members of the genera Flavobacterium, Cytophaga, Flexibacter, Sphingobacterium, Capnocytophaga, and Weeksella and some other organisms constitute a separate eubacterial lineage within the group of gramnegative bacteria. This lineage has been named rRNA superfamily $\mathrm{V}(12,31)$. Comparisons of $16 \mathrm{~S}$ rRNA sequences of some of these taxa led to similar conclusions $(15,41)$. So far, we have found five major rRNA homology groups within this rRNA superfamily. The first rRNA homology group contains four different rRNA branches (Fig. 1). R. anatipestifer and $W$. zoohelcum each constitutes a separate rRNA branch; Flavobacterium indologenes, Flavobacterium gleum, Flavobacterium indoltheticum, and Flavobacterium balustinum constitute a third rRNA branch, while Flavobacterium meningosepticum occupies a separate position at the linkage level of the three other rRNA branches and as such constitutes a separate rRNA branch.

At present, the second rRNA homology group contains a single rRNA branch comprising Flavobacterium breve and Weeksella virosa (Fig. 1). The difference in $T_{m(e)}$ of $7.5^{\circ} \mathrm{C}$ in comparisons with rRNA of Flavobacterium breve reflects a considerable genomic divergence between the two taxa.

The third rRNA homology group contains two rRNA branches and includes species belonging to the genera Flavobacterium, Cytophaga, and Flexibacter. Again, the large differences in $T_{m(e)}$ values found in comparisons with the two types of rRNAs revealed that there is wide genomic heterogeneity within this rRNA cluster. Only two of the Flavobacterium species belonging to this rRNA homology group, Flavobacterium aquatile and Flavobacterium odoratum, are described as valid species in Bergey's Manual of Systematic Bacteriology (18). Furthermore, the taxonomic status of 


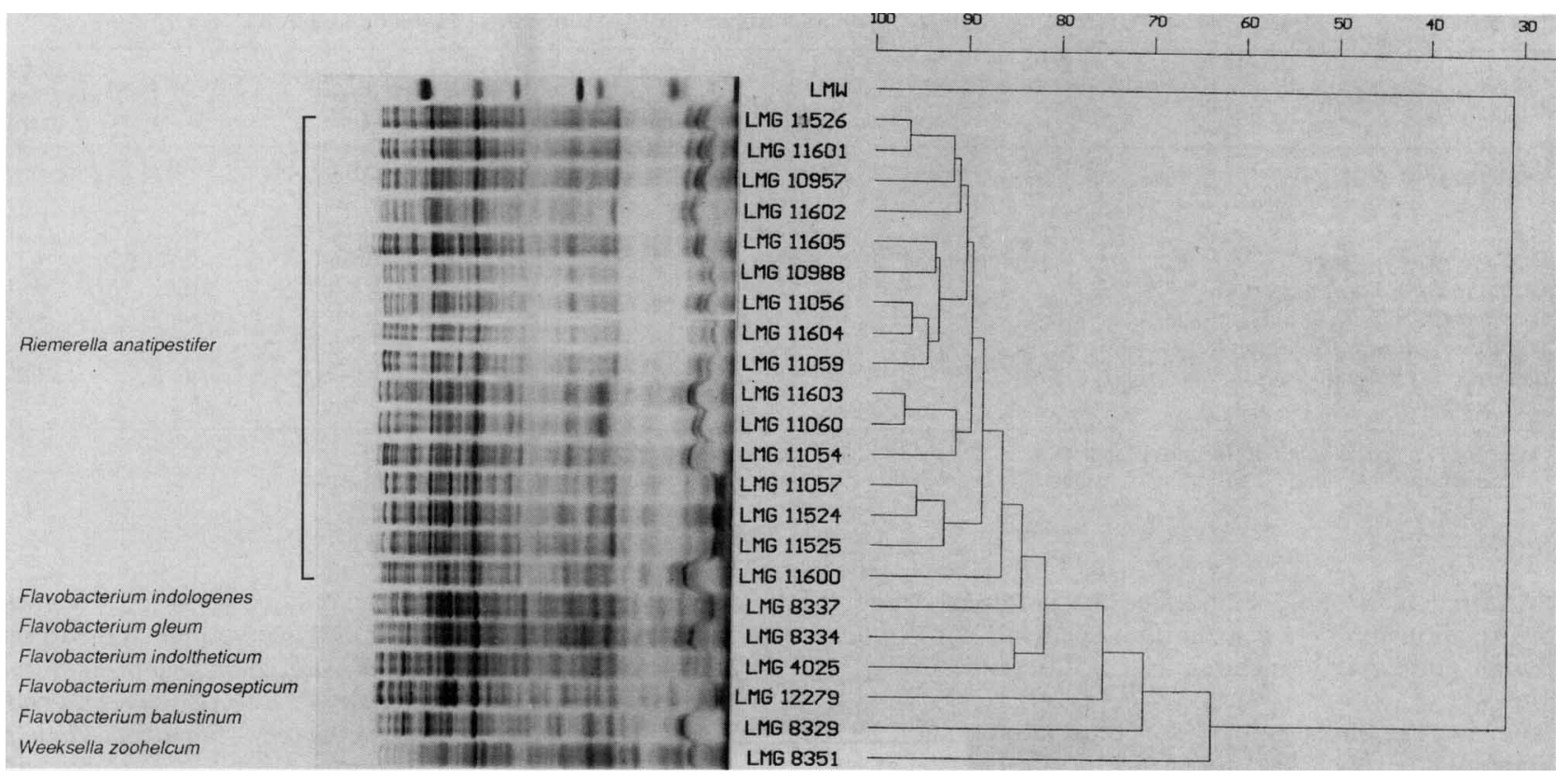

FIG. 2. Protein profiles of strains listed in Table 1 and corresponding dendrogram derived from unweighed pair group average linkage of Pearson product moment correlation coefficients (expressed for convenience as percentages). The positions of the molecular weight markers (track LMW) were as follows (from right to left): lysozyme, 14,500; trypsin inhibitor, 20,100; trypsinogen, 24,000; carbonic anhydrase, 29,000; glyceraldehyde-3-phosphate dehydrogenase, 36,000; egg albumin, 45,000; and bovine albumin, 66,000.

Flavobacterium aquatile as the type species of the genus Flavobacterium has been the subject of much controversy; most often this organism is not considered a true Flavobacterium species $(16,17)$. The type species of the genera Cytophaga and Flexibacter, Cytophaga hutchinsonii and Flexibacter flexilis, respectively, do not belong to this rRNA homology group, which implies that all Cytophaga and Flexibacter species belonging to this rRNA homology group are generically misnamed. Obviously, the remaining Cyto- phaga and Flexibacter species should be included in an analysis, and more labelled rRNAs have to be prepared in order to determine the detailed genotypic structure of this complex rRNA homology group. Only then can a significant taxonomic revision be proposed.

The Capnocytophaga species studied so far form a separate fourth rRNA homology group represented by a single rRNA branch (Fig. 1). Capnocytophaga sputigena and Capnocytophaga ochracea cluster together at the top of this

TABLE 3. Fatty acid compositions of the organisms studied ${ }^{a}$

\begin{tabular}{|c|c|c|c|c|c|c|c|}
\hline \multirow[b]{2}{*}{ Fatty acid } & \multicolumn{7}{|c|}{$\%$ in: } \\
\hline & $\begin{array}{l}\text { R. anatipestifer } \\
\text { (16 strains) }\end{array}$ & $\begin{array}{c}\text { Flavobacterium } \\
\text { gleum } \\
\text { LMG } 8334^{T}\end{array}$ & $\begin{array}{c}\text { Flavobacterium } \\
\text { indologenes } \\
\text { LMG } 8337^{\mathrm{T}}\end{array}$ & $\begin{array}{l}\text { Flavobacterium } \\
\text { balustinum } \\
\text { LMG } 8329^{\mathrm{T}}\end{array}$ & $\begin{array}{c}\text { Flavobacterium } \\
\text { indoltheticum } \\
\text { LMG } 4025^{\mathrm{Tb}}\end{array}$ & $\begin{array}{c}\text { Flavobacterium } \\
\text { meningosepticum } \\
\text { LMG } 12279^{\mathrm{T}}\end{array}$ & $\begin{array}{l}\text { W. zoohelcum } \\
\text { LMG } 8351^{\text {Tc }}\end{array}$ \\
\hline $13: 0$ iso & $14.9 \pm 3.6(16)$ & $\operatorname{Tr}$ & $\operatorname{Tr}$ & $\operatorname{Tr}$ & $\operatorname{Tr}$ & 1.9 & 3.6 \\
\hline ECL $13.566^{d}$ & $1.5 \pm 0.6(16)$ & 2.1 & 2.2 & 2.6 & $\operatorname{Tr}$ & 1.4 & 1.5 \\
\hline $15: 0$ iso & $52.8 \pm 4.9(16)$ & 35.5 & 34.8 & 31.1 & 34.1 & 42.1 & 61.9 \\
\hline $15: 0$ anteiso & $5.8 \pm 1.8(16)$ & ND & $\operatorname{Tr}$ & 1.1 & 5.3 & 1.9 & ND \\
\hline $\mathrm{SF} 4^{e}$ & ND & 13.3 & 11.6 & 8.9 & 10.2 & 17.3 & 6.4 \\
\hline $16: 0$ & $\operatorname{Tr}(8)$ & 1.0 & 1.2 & 2.7 & 1.3 & $\operatorname{Tr}$ & ND \\
\hline $15: 0$ iso $3 \mathrm{OH}$ & $8.0 \pm 2.8(16)$ & 3.0 & 2.8 & 2.6 & 2.0 & 3.7 & 4.1 \\
\hline iso $17: 1 \omega 9 \mathrm{c}$ & ND & 19.1 & 19.8 & 26.3 & 21.7 & 4.6 & 9.1 \\
\hline ECL 16.580 & $\operatorname{Tr}(12)$ & 1.9 & 1.6 & 1.4 & 1.4 & 1.7 & ND \\
\hline $17: 0$ iso & ND & 1.3 & 1.1 & 1.7 & 1.0 & $\operatorname{Tr}$ & $\mathrm{Tr}$ \\
\hline $16: 0$ iso $3 \mathrm{OH}$ & $0.9 \pm 0.6(15)$ & $\operatorname{Tr}$ & $\operatorname{Tr}$ & $\operatorname{Tr}$ & $\operatorname{Tr}$ & 1.1 & ND \\
\hline $16: 03 \mathrm{OH}$ & ND & 1.1 & 1.2 & 1.5 & 1.1 & 2.3 & ND \\
\hline $17: 0$ iso $3 \mathrm{OH}$ & $13.1 \pm 3.5(16)$ & 20.6 & 20.5 & 15.1 & 15.4 & 17.6 & 9.9 \\
\hline
\end{tabular}

${ }^{a}$ Those fatty acids which account for less than $1 \%$ of the total fatty acids in all strains studied are not shown. Therefore, the percentages do not total $100 \%$.

For $R$. anatipestifer, the means, standard deviations, and numbers of strains containing the fatty acids (values in parentheses) are shown. Tr, trace (less than $1.0 \%$; ND, not detected.

${ }^{b}$ Flavobacterium indoltheticum LMG $4025^{\mathrm{T}}$ also contains $2.7 \%$ 17:0 $2 \mathrm{OH}$.

c W. zoohelcum LMG $8351^{\mathrm{T}}$ also contains $1.5 \%$ summed feature 5 (i.e., 17:1 iso I or 17:1 anteiso B or both).

${ }^{d}$ ECL, equivalent chain length. The identity of the fatty acid is unknown.

e SF 4, summed feature 4 (15:0 iso $2 \mathrm{OH}$ or $16: 1 \omega 7 \mathrm{t}$ or both). 
TABLE 4. Differentiating phenotypic characteristics for $R$. anatipestifer and allied bacteria ${ }^{a}$

\begin{tabular}{|c|c|c|c|c|c|c|c|c|}
\hline Species & $\begin{array}{l}\text { Production of } \\
\text { indole }\end{array}$ & $\begin{array}{l}\text { Pigment } \\
\text { production }\end{array}$ & $\begin{array}{c}\text { Nitrate } \\
\text { reduction }\end{array}$ & $\begin{array}{c}\beta- \\
\text { Galactosidase } \\
\text { activity }\end{array}$ & $\begin{array}{l}\text { Urease } \\
\text { activity }\end{array}$ & $\begin{array}{l}\text { Optimal } \\
\text { growth } \\
\text { conditions }\end{array}$ & $\begin{array}{l}\text { Growth at } \\
42^{\circ} \mathrm{C}\end{array}$ & $\begin{array}{l}\text { Growth on } \\
\text { MacConkey } \\
\text { agar }\end{array}$ \\
\hline R. anatipestifer & $-{ }^{b}$ & - & - & - & d & $\begin{array}{c}\text { Microaerobic } \\
\text { with } \mathrm{CO}_{2} \\
\text { enrichment }\end{array}$ & $(+)$ & - \\
\hline Flavobacterium gleum & + & + & d & d & d & Aerobic & d & + \\
\hline Flavobacterium indologenes & + & + & d & d & - & Aerobic & d & d \\
\hline Flavobacterium balustinum & + & + & + & - & - & Aerobic & - & + \\
\hline Flavobacterium indoltheticum & + & + & - & - & - & Aerobic & - & + \\
\hline Flavobacterium meningosepticum & d & + & $(-)$ & $(+)$ & d & Aerobic & d & + \\
\hline W. zoohelcum & + & - & - & - & + & Aerobic & $(-)$ & - \\
\hline
\end{tabular}

${ }^{a}$ Data for Flavobacterium and Weeksella species were obtained from references 6, 19, 20, and 42 .

${ }^{b}+$, present in all strains; - , absent in all strains; $(+)$, present in most strains; $(-)$, absent in most strains; d, strain dependent.

rRNA branch, which corroborates the previously reported close relationship between the two species (34). Capnocytophaga gingivalis branches off at a difference in $T_{m(e)}$ of about $5^{\circ} \mathrm{C}$.

The average linkage level for these four major rRNA homology groups is a $T_{m(e)}$ of $65.1 \pm 1.5^{\circ} \mathrm{C}$. This value is the average from 66 hybridizations between representatives of the four groups. It is obvious that organisms belonging to the different rRNA homology groups [with differences in $T_{m(e)}$ of about 11 to $14^{\circ} \mathrm{C}$ ] cannot belong to a single genus. Even within most of the rRNA homology groups, the range of $T_{m(e)}$ values is so wide that, theoretically, several genera can be delineated, provided that the division is based on solid chemotaxonomic or other phenotypic grounds.

A fifth rRNA homology group is linked to the other groups at $T_{m(e)}$ of $59.9 \pm 2.0^{\circ} \mathrm{C}$ (average of 11 values). Until now, this cluster contained two rRNA branches. The first rRNA branch consists of Cytophaga heparina and various other, as-yet-unnamed, heparin-degrading isolates $(35,36)$. The second rRNA branch contains the three Sphingobacterium species and Flavobacterium yabuuchiae, which exhibits high DNA homology values with Sphingobacterium spiritivorum (21). Flavobacterium thalpophilum and Flexibacter canadensis are situated at the base level between the two rRNA branches. Clearly, Flavobacterium thalpophilum, which is also a sphingophospholipid-producing organism, can be included in the genus Sphingobacterium on genotypic grounds as well. Finally, Flexibacter flexilis, "Flexibacter elegans," and Cytophaga hutchinsonii occupy separate positions on the $T_{m(e)}$ dendrogram (Fig. 1).

For a considerable number of taxa included in this study, the 16S rRNA sequence of a representative strain has been determined (15). Sequence comparison of $16 \mathrm{~S}$ rRNAs is a more powerful tool than DNA-rRNA hybridization analysis for resolving taxonomic relationships at the deeper phylogenetic level (41). However, the detailed structure of the various subclusters is strongly influenced by the choice of outgroup, and the clustering sequence can be altered by another outgroup taxon (28). Despite the differences in branching order, the major groups obtained in the two studies are similar and, logically, lead to the same conclusions: the genera Flavobacterium, Cytophaga, Flexibacter, and Weeksella are polyphyletic genera which should be redefined, whereas the genera Capnocytophaga, Sphingobacterium, and Riemerella are genotypically well defined. A revision of the taxonomy of the former genera is overdue but would be premature until all present members of these genera are studied.
The following taxa exhibited only very low $T_{m(e)}$ values in comparisons with all of the reference strains studied (Table 2): Flavobacterium acidificum, Flavobacterium acidurans, "Flavobacterium dehydrogenans," "Flavobacterium denitrificans," Flavobacterium ferrugineum, "Flavobacterium fuscum," Flavobacterium marinotypicum, "Flavobacterium marinovirosum," Flavobacterium okeanokoites, "Flavobacterium proteus," Flavobacterium resinovorum, Flavobacterium thermophilum, Flexibacter roseolus, Flexibacter ruber, Saprospira grandis, Bacteroides fragilis, and Bacteroides oralis. The exact phylogenetic position of these taxa is not the subject of this paper and will be dealt with separately.

Differentiation of $R$. anatipestifer from its closest relatives. Flavobacterium gleum, Flavobacterium indologenes, Flavobacterium indoltheticum, Flavobacterium balustinum, Flavobacterium meningosepticum, and $W$. zoohelcum belong to the same rRNA homology group as $R$. anatipestifer. These taxa are situated on the dendrogram at a difference in $T_{m(e)}$ of about $5^{\circ} \mathrm{C}$. This difference in $T_{m(e)}$ reflects a genomic divergence between $R$. anatipestifer and its allies which is large enough to warrant separate generic status for $R$. anatipestifer, provided that a sufficient number of differentiating chemotaxonomic or other features are available. $R$. anatipestifer can be distinguished from its neighbors by its capnophilic metabolism, by the absence of pigments, and by its fatty acid (Table 3 ) and protein (Fig. 2) contents. The overall fatty acid pattern is in agreement with previously published data $(22,37)$. Furthermore, the type strain of $R$. anatipestifer contains menaquinone 7 as its sole respiratory quinone (13), whereas the flavobacteria belonging to this rRNA homology group contain menaquinone $6(9)$. No data on the quinone content of $W$. zoohelcum are available. Additional phenotypic features useful for differentiating $R$. anatipestifer from its closest neighbors are shown in Table 4. These phenotypic data and the features listed in the description given below were obtained from references 3,6 through $8,13,27,29$, and 33 .

Clearly, $R$. anatipestifer is very different from its relatives in many aspects. We therefore concluded that a separate genus for this taxon is justified on the basis of genotypic and phenotypic criteria. DNA-DNA hybridization studies with $R$. anatipestifer revealed high levels of intraspecies DNA homology $(2,27,29)$.

Description of the genus Riemerella gen. nov. Riemerella (Rie.me.rel'la. proper name Riemer; L. dim. suf. ella; N. L. fem. n. Riemerella, named in honor of Riemer, who first described $R$. anatipestifer infections in geese in 1904 and 
referred to the disease as septicemia anserum exsudativa [30]). Cells are gram-negative, nonsporulating rods. Most strains grow aerobically and microaerobically after primary isolation in a $\mathrm{CO}_{2}$-enriched atmosphere. $\mathrm{A}$ number of carbohydrates are weakly acidified or fermented. At present it is not possible to give a general biochemical profile for the genus as only a single species is known.

The type species is $R$. anatipestifer. The DNA base composition ranges from 29 to $35 \mathrm{~mol} \% \mathrm{G}+\mathrm{C}$.

Description of Riemerella anatipestifer comb. nov. Riemerella anatipestifer (a.na.ti.pes'ti.fer. L. n. anas, duck; L. n. pestifer, trouble bearer; N. L. n. anatipestifer, cause of a disease in ducks). It must be emphasized that the specific epithet anatipestifer is kept in order to avoid nomenclatural confusion; the illness caused by this organism is a septicemic disease which is not restricted to ducks. The description of $R$. anatipestifer is the same as the description of the genus. $R$. anatipestifer cells are gram-negative, nonmotile, nonsporulating rods that are 0.3 to $0.5 \mu \mathrm{m}$ wide and 1 to $2.5 \mu \mathrm{m}$ long and occur singly, in pairs, or in short chains. Gliding motility is not observed. Smooth, nonpigmented colonies are developed within 2 days during microaerobic incubation on rich peptone, peptone-blood, or chocolate agar at $36^{\circ} \mathrm{C}$. Optimal growth occurs at $37^{\circ} \mathrm{C}$; most strains grow at $45^{\circ} \mathrm{C}$ but not at $4^{\circ} \mathrm{C}$. Requires thiamine, but low concentrations of pyrithiamine and amprolium are inhibitory. Nitrates are not reduced. Urease and chymotrypsin activities, hemolysis, and the litmus milk reaction are strain dependent. Indole is not produced. Most strains liquefy gelatin, Löffler's blood serum, and coagulated egg medium. Growth occurs in Huddleson's thionine medium, in Huddleson's basic fuchsin medium, and on agar containing $10 \%$ bile in serum. No growth occurs on agar containing $40 \%$ bile in serum, citrate agar, or MacConkey agar or in $\mathrm{KCN}$ broth or glycerol phosphate medium. Hydrogen sulfide is not produced. The following enzyme activities are present: oxidase, catalase, alkaline and acid phosphatase, ester lipase $\mathrm{C} 8$, leucine arylamidase, valine arylamidase, cystine arylamidase, phosphoamidase, $\alpha$-glucosidase, and esterase $C 4$. The following enzyme activities are absent: $\alpha$ - and $\beta$-galactosidases, $\beta$-glucuronidase, $\beta$-glucosidase, $\alpha$-mannosidase, $\beta$-glucosaminidase, lipase $\mathrm{C} 14$, fucosidase, trypsin, ornithine and lysine decarboxylases, and phenylalanine deaminase. Highly susceptible to penicillin and highly resistant to polymixin $\mathbf{B}$ and kanamycin.

Menaquinone 7 is the sole respiratory quinone detected in the type strain. The fatty acids include branched fatty acids 13:0 iso, 15:0 iso, 15:0 anteiso, 15:0 iso $3 \mathrm{OH}$, and 17:0 iso $3 \mathrm{OH}$ and an unidentified fatty acid with an equivalent chain length of 13.566 .

Isolated from ducks, geese, turkeys, and waterfowl with septicemic disease. $R$. anatipestifer is important in veterinary medicine as it is distributed worldwide and causes serious problems in commercial duck, goose, and turkey flocks $(23,27)$. Furthermore, strains have also been isolated from muscovy ducks, chickens, pheasants, quails, and wild free-living waterfowl.

The type strain is LMG 11054 (= ATCC $11845=$ MCCM $00568=$ CCUG 14215), which was isolated from a duck in the United States. Its $\mathrm{G}+\mathrm{C}$ content is $35 \mathrm{~mol} \%$.

\section{ACKNOWLEDGMENTS}

We thank Urbain Torck and Dirk Dewettinck for excellent technical assistance. We are especially grateful to T. O. MacAdoo, Department of Foreign Languages, Virginia Polytechnic Institute and State University, Blacksburg, for expert advice in naming
Riemerella anatipestifer. We thank all depositors of strains listed in Table 1.

Part of this research was performed in the framework of CEC BRIDGE project BIOT-CT91-0294. P.V. is indebted to the National Fund for Scientific Research (Belgium) for a position as a postdoctoral researcher. K.K. is indebted to the Fund for Medical Scientific Research, Belgium, for research and personnel grants.

\section{REFERENCES}

1. Aiba, H., S. Adhya, and B. de Crombrugghe. 1981. Evidence for two functional gal promotors in intact Escherichia coli cells. J. Biol. Chem. 256:11905-11910.

2. Bangun, A., J. L. Johnson, and D. N. Tripathy. 1987. Taxonomy of Pasteurella anatipestifer. I. DNA base composition and DNA-DNA hybridization analysis. Avian Dis. 31:43-45.

3. Bangun, A., D. N. Tripathy, and L. E. Hanson. 1981. Studies of Pasteurella anatipestifer: an approach to its classification. Avian Dis. 25:326-337.

4. Bauwens, M., and J. De Ley. 1981. Improvements in the taxonomy of Flavobacterium by DNA:rRNA hybridizations, p. 27-31. In H. Reichenbach and O. B. Weeks (ed.), The Flavobacterium-Cytophaga group. Gesellschaft für Biotechnologische Forschung mbH monograph series no. 5. Verlag Chemie, Weinheim, Germany.

5. Bøvre, K. 1984. Genus II. Moraxella Lwoff 1939, 173 emend. Henriksen and Bøvre 1968, 391 AL, p. 296-303. In N. R. Krieg and J. G. Holt (ed.), Bergey's manual of systematic bacteriology, vol. 1. The Williams \& Wilkins Co., Baltimore.

6. Breed, R. S., E. G. D. Murray, and N. R. Smith. (ed.). 1957. Bergey's manual of determinative bacteriology, 7th ed. Williams and Wilkins, Baltimore.

7. Brogden, K. A. 1989. Pasteurella anatipestifer infection, p. 115-129. In C. Adlam and J. M. Rutter (ed.), Pasteurella and pasteurellosis. Academic Press, London.

8. Brogden, K. A., K. R. Rhoades, and R. B. Rimler. 1982. Serologic types and physiologic characteristics of 46 avian Pasteurella anatipestifer cultures. Avian Dis. 26:891-896.

9. Dees, S. B., G. M. Carlone, D. Hollis, and C. W. Moss. 1985. Chemical and phenotypic characteristics of Flavobacterium thalpophilum compared with those of other Flavobacterium and Sphingobacterium species. Int. J. Syst. Bacteriol. 35:16-22.

10. De Ley, J. 1970. Reexamination of the association between melting point, buoyant density, and chemical base composition of deoxyribonucleic acid. J. Bacteriol. 101:738-754.

11. De Ley, J., and J. De Smedt. 1975. Improvements on the membrane filter method for DNA:rRNA hybridization. Antonie van Leeuwenhoek J. Microbiol. Serol. 41:287-307.

12. De Vos, P., A. Van Landschoot, P. Segers, R. Tytgat, M. Gillis, M. Bauwens, R. Rossau, M. Goor, B. Pot, K. Kersters, P. Lizzaraga, and J. De Ley. 1989. Genotypic relationships and taxonomic localization of unclassified Pseudomonas and Pseudomonas-like strains by deoxyribonucleic acid-ribosomal ribonucleic acid hybridizations. Int. J. Syst. Bacteriol. 39:3549.

13. Engelhard, E. 1992. Untersuchungen zur Chemotaxonomie der Familie Pasteurellaceae anhand von Kapillargaschromatographie zellulärer Kolenhydrate, Hochdruckflüssigkeitschromatographie und Dünnschichtchromatographie zellulärer Lipoide, verschiedener Hydrolasen und Infrarot-Massenspektroskopie. $\mathrm{Ph}$.D. thesis. Philipps-Universität, Marburg, Germany.

14. Floren, U., B. Wiedeking, B. Kissel, and E. F. Kaleta. 1987. Pasteurella anatipestifer-Infektion des Wassergeflügels. Dtsch. Tieraerztl. Wochenschr. 94:525-534.

15. Gherna, R., and C. R. Woese. 1992. A partial phylogenetic analysis of the "flavobacter-bacteroides" phylum: basis for taxonomic restructuring. Syst. Appl. Microbiol. 15:513-521.

16. Holmes, B. 1991. The genera Flavobacterium, Sphingobacterium, and Weeksella, p. 3620-3630. In A. Balows, H. G. Trüper, M. Dworkin, W. Harder, and K.-H. Schleifer (ed.), The prokaryotes, 2nd ed., vol. 3. Springer-Verlag, Berlin.

17. Holmes, B., and R. J. Owen. 1979. Proposal that Flavobacterium breve be substituted as the type species of the genus in place of Flavobacterium aquatile and emended description of 
the genus Flavobacterium: status of the named species of Flavobacterium. Int. J. Syst. Bacteriol. 29:416-426.

18. Holmes, B., R. J. Owen, and T. A. McMeekin. 1984. Genus Flavobacterium Bergey, Harrison, Breed, Hammer, and Huntoon 1923, 97 ${ }^{\mathrm{AL}}$, p. 353-361. In N. R. Krieg and J. G. Holt (ed.), Bergey's manual of systematic bacteriology, vol. 1. The Williams \& Wilkins Co., Baltimore.

19. Holmes, B., R. J. Owen, A. G. Steigerwalt, and D. J. Brenner. 1984. Flavobacterium gleum, a new species found in human clinical specimens. Int. J. Syst. Bacteriol. 34:21-25.

20. Holmes, B., A. G. Steigerwalt, R. E. Weaver, and D. J. Brenner. 1986. Weeksella zoohelcum sp. nov. (formerly group IIj), from human clinical specimens. Syst. Appl. Microbiol. 8:191-196.

21. Holmes, B., R. E. Weaver, A. G. Steigerwalt, and D. J. Brenner. 1988. A taxonomic study of Flavobacterium spiritivorum and Sphingobacterium mizutae: proposal of Flavobacterium yabuuchiae sp. nov. and Flavobacterium mizutaii comb. nov. Int. J. Syst. Bacteriol. 38:348-353.

22. Lambert, M. A., and C. W. Moss. 1984. Cellular fatty acid compositions of Moraxella anatipestifer and Legionella pneumophila. Int. J. Syst. Bacteriol. 34:490-491.

23. Loh, H., T. P. Teo, and H.-C. Tan. 1992. Serotypes of 'Pasteurella' anatipestifer isolates from ducks in Singapore: a proposal of new serotypes. Avian Pathol. 21:453-459.

24. Mannheim, W. 1984. Family III. Pasteurellaceae Pohl 1981a, $382^{\mathrm{VP}}$, p. 550-557. In N. R. Krieg and J. G. Holt (ed.), Bergey's manual of systematic bacteriology, vol. 1. The Williams \& Wilkins Co., Baltimore.

25. Marmur, J., and P. Doty. 1962. Determination of the base composition of deoxyribonucleic acid from its thermal denaturation temperature. J. Mol. Biol. 5:109-118.

26. Moss, C. W., and S. B. Dees. 1978. Cellular fatty acids of Flavobacterium meningosepticum and Flavobacterium species group IIb. J. Clin. Microbiol. 8:772-774.

27. Mouahid, M., K.-H. Hinz, R. Mutters, and W. Mannheim. Submitted for publication.

28. Paster, B. J., and F. E. Dewhirst. 1988. Phylogeny of campylobacters, wolinellas, Bacteroides gracilis, and Bacteroides ureolyticus by $16 \mathrm{~S}$ ribosomal ribonucleic acid sequencing. Int. J. Syst. Bacteriol. 38:56-62.

29. Piechulla, K., S. Pohl, and W. Mannheim. 1986. Phenotypic and genetic relationships of so-called Moraxella (Pasteurella) anatipestifer to the Flavobacterium/Cytophaga group. Vet. Microbiol. 11:261-270.

30. Riemer. 1904. Kurze Mitteilung über eine bei Gänsen beobachtete exsudative Septikämie und deren Erreger. Zentralbl. Bakteriol. Abt. 1 37:641-648.

31. Rossau, R., A. Van Landschoot, M. Gillis, and J. De Ley. 1991. Taxonomy of Moraxellaceae fam. nov., a new bacterial family to accommodate the genera Moraxella, Acinetobacter, and Psychrobacter and related organisms. Int. J. Syst. Bacteriol. 41:310-319.

32. Segers, P., P. Vandamme, P. L. Steyn, W. Mannheim, H. Willekens, M. Bauwens, J. De Ley, and K. Kersters. Phylogenetic studies of Flavobacterium and related organisms. In Proceedings of the Second International Symposium on Flavobacterium-Cytophaga and related bacteria, in press.

33. Smith, J. E. 1974. Genus Pasteurella Trevisan 1887, 94 Nom cons. Opin. 13, Jud. Comm. 1954, 153, p. 370-373. In R. E. Buchanan and N. E. Gibbons (ed.), Bergey's manual of determinative bacteriology, 8th ed. The Williams \& Wilkins Co., Baltimore.

34. Speck, H., R. M. Kroppenstedt, and W. Mannheim. 1987. Genomic relationships and species differentiation in the genus Capnocytophaga. Zentralbl. Bakteriol. Parasitenkd. Infektionskr. Hyg. Abt. 1 Orig. Reihe A 266:390-402.

35. Steyn, P. L., B. Pot, P. Segers, K. Kersters, and J. J. Joubert. 1992. Some novel aerobic heparin-degrading bacterial isolates. Syst. Appl. Microbiol. 15:137-143.

36. Steyn, P. L., P. Segers, M. Vancanneyt, B. Pot, K. Kersters, and J. J. Joubert. Unpublished data.

37. Sugimoto, C., E. Miyagawa, M. Nakazawa, K. Mitani, and Y. Isayama. 1983. Cellular fatty acid composition comparisons of Haemophilus equigenitalis and Moraxella species. Int. J. Syst. Bacteriol. 33:181-187.

38. Vandamme, P., P. Segers, M. Vancaneyt, K. Van Hove, R. Mutters, J. Hommez, F. Dewhirst, B. Paster, K. Kersters, E. Falsen, L. Devrieze, K.-H. Hinz, and W. Mannheim. Submitted for publication.

39. Vandamme, P., M. Vancanneyt, B. Pot, L. Mels, B. Hoste, D. Dewettinck, L. Vlaes, C. Van Den Borre, R. Higgins, J. Hommez, K. Kersters, J.-P. Butzler, and H. Goossens. 1992. Polyphasic taxonomic study of the emended genus Arcobacter with Arcobacter butzleri comb. nov. and Arcobacter skirrowii sp. nov., an aerotolerant bacterium isolated from veterinary specimens. Int. J. Syst. Bacteriol. 42:344-356.

40. Vauterin, L., J. Swings, and K. Kersters. 1991. Grouping of Xanthomonas campestris pathovars by SDS-PAGE of proteins. J. Gen. Microbiol. 137:1677-1687.

41. Woese, C. R. 1987. Bacterial evolution. Microbiol. Rev. 51:221271.

42. Yabuuchi, E., T. Kaneko, I. Yano, C. W. Moss, and N. Miyoshi. 1983. Sphingobacterium gen. nov., Sphingobacterium spiritivorum comb. nov., Sphingobacterium multivorum comb. nov., Sphingobacterium mizutae sp. nov., and Flavobacterium indologenes sp. nov.: glucose-nonfermenting gram-negative rods in CDC groups IIK-2 and IIb. Int. J. Syst. Bacteriol. 33:580 598. 